\section{Francis Guthrie: A Colourful Life}

\section{Pieter Maritz and Sonja Mouton}

Does your hometown have any mathematical tourist attractions such as statues, plaques, graves, the café where the famous conjecture was made, the desk where the famous initials are scratched, birthplaces, bouses, or memorials? Have you encountered a mathematical sight on your travels? If so, we invite you to submit an essay to this column. Be sure to include a picture, a description of its mathematical significance, and either a map or directions so that others may follow in your tracks.

> Please send all submissions to Mathematical Tourist Editor,

Dirk Huylebrouck, Aartshertogstraat 42,

8400 Oostende, Belgium

e-mail: huylebrouck@gmail.com n 1852, in London, Francis Guthrie posed the question of colouring a map with four colours only, the question that eventually became known as the Four-Colour Problem. The problem is famous, but what else do we know of Guthrie's work and life? Don't try to track him in London; come to South Africa instead.

\section{Biographical Background}

Francis Guthrie was born in Bayswater, Paddington, England, on January 22, 1831. His parents, Alexander David Guthrie, a London tradesman, and Kitty Guthrie (born Thompson) [7](d), had two sons, Francis and Frederick. It was unheard of that a successful tradesman would send his sons to university; normally they would have followed in their father's footsteps. These sons, however, were fortunate to have been brought up in an enlightened family, and this is, no doubt, the reason for their ability to look at life differently and to embrace it with enthusiasm and open minds.

Francis Guthrie was educated at the University College of London, where he graduated with a B.A. and an LL.B., obtaining first-class honours in both. Although he practised as a barrister in London for some years, his main interest lay in mathematics, and in 1861 he travelled to the Cape Colony to take up the chair of Mathematics at the newly established Graaff-Reinet College, a position he would hold for 14 years. In Graaff-Reinet in 1871, Guthrie married Charlotte Isabella Grisbrook, a daughter of a local medical practitioner and pharmacist [4]. There were two sons and two daughters of the marriage: Francis Alexander Charles, Margaret Mary, Frederick Gysbert (Bertie), and Isabel Louise Sophy (Louise).

Also in Graaff-Reinet, Guthrie met Harry Bolus, who became his lifelong friend. Bolus was born in 1834 in Nottingham, England, and he arrived in Algoa Bay (the present Port Elizabeth) in 1850, proceeding first to Grahamstown and within a few years to Graaff-Reinet, where it seems he worked as a lithographer and reporter for the Graaff-Reinet Herald. From there he went to Cape Town, where he entered a partnership with his brother Walter, starting Bolus Brothers, the first firm of stockbrokers in Cape Town. The Guthries moved from Graaff-Reinet to Cape Town in 1875. After two years as a barrister (this time at the Supreme Court in Cape Town) and also editing the Daily News, Guthrie was appointed at the South African College and returned to lecturing mathematics [1].

\section{The Four-Colour Problem}

In 1852, as a law student in England trying to colour a map of England's counties, Guthrie found he needed at least four different colours if two regions sharing a border could not share a colour. He then conjectured, and attempted to prove, that four colours sufficed to colour any map in this way. This 
was the birth of the famous Four-Colour Problem, or FourColour Conjecture [10].

Since his brother was at the time a student of Augustus de Morgan, Guthrie asked him to convey the details of the problem to De Morgan (who had taught Francis previously). Frederick wrote later [5] that De Morgan was very pleased with Francis's work and always gave him due credit whenever the Four-Colour Problem came up. Frederick also mentioned that Francis had not been satisfied with his own (attempted) proof, but instead of sharing his brother's arguments in this note, he wrote "but the critical diagram was as in the margin"!

On the very day Frederick asked him the question, De Morgan wrote to his friend Sir William R. Hamilton, the distinguished Irish mathematician and physicist of Dublin: "A student of mine asked me today to give him a reason for a fact which I did not know was a fact-and do not yet. ... If you retort with some very simple case which makes me out a stupid animal, I think I must do as the Sphynx did" De Morgan had hoped that Hamilton would become interested in the map-colour problem, but the latter replied: "I am not likely to attempt your 'quaternion' of colours very soon."

De Morgan wrote to other friends trying to interest them in the problem. It remained one of the most famous unsolved problems in topology and graph theory for more than a century, until it was finally proven in 1976 with the aid of computer algorithms [10]. Francis Guthrie himself wrote nothing more about it.

\section{The Graaff-Reinet College}

James Rose Innes, the Cape Colony's first superintendentgeneral of education, proposed establishing a college in Graaff-Reinet about 1858. This suggestion was met with great enthusiasm by the people of the town, who immediately started to raise money. As envisioned, the institution was to have both preparatory (high school) and higher (university) departments of study. A governing body was put in place that advertised in the colony for professorships for the higher departments. None of the eleven applicants was deemed good enough; eventually two suitable academics from
England were identified. James Gill, a scholar of Cambridge, became the Professor of Classics, and Francis Guthrie was offered the Mathematics chair [3]. Guthrie, Gill, and the Rev. Andrew Murray and Canon Steabler (as representatives of the governing body) formed the first academic senate [6].

The opening of the Graaff-Reinet College was a ceremony in true college tradition. The audience included approximately 20 enrolled students. They were all white boys; the education of girls and nonwhite people would only be developed later. Several optimistic and encouraging speeches were made, after which the procession marched to the building on Somerset Street where their temporary classrooms were. This building was the previous location of a store belonging to Walter and Harry Bolus.

The decade that followed was one of academic success, including financial stability and collegiate growth. Both Gill and Guthrie were well qualified and were committed to maintaining high standards in education, as well as being active members of the Graaff-Reinet community. The period of prosperity that followed was in no small measure due to Guthrie's excellence and complete involvement. The GraaffReinet College would become quite famous as a result of his students' achievements in mathematics.

The governing body initially concentrated on the higher division and completely neglected to develop the planned preparatory school. This proved to be a serious mistake, because both the best local private school and the government school were closing as a result of financial problems. In June 1864 the preparatory school officially closed [3]. A month later the Graaff-Reinet College moved into its new premises on Bourke Street, where it would be based for more than 40 years [6]. The original College Building no longer exists, and a provincial building currently occupies the site.

The Board of Public Examiners in Literature and Science in Cape Town offered a written examination for a third-class certificate of matriculation standard. This, as well as the firstand second-class certificate examinations (which were similar to the M.A. and B.A. degrees of the University College of London), were open to all students in the Colony. At the



PIETER MARITZ was born in South Africa and holds the degree of Dr. Wisk. Nat. from the University of Leiden in the Netherlands. His research interests include measure theory, the theory and applications of vector measures and multifunctions, and the history of mathematics and mathematics education. He enjoys hiking in the mountains of the Western Cape region and gardening; he also has some interest in philately.

Department of Mathematical Sciences University of Stellenbosch

Private Bag XI, Matieland 7602

South Africa

e-mail: pm@sun.ac.za

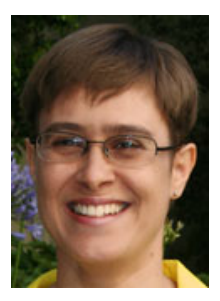

SONJA MOUTON was born in South Africa and holds a Ph.D. from the University of the Orange Free State in Bloemfontein, South Africa. Her main contribution to mathematics is in spectral theory in Banach algebras. Other interests include playing the piano and caring for her five guinea pigs.

Department of Mathematical Sciences

University of Stellenbosch

Private Bag XI, Matieland 7602

South Africa

e-mail: smo@sun.ac.za 


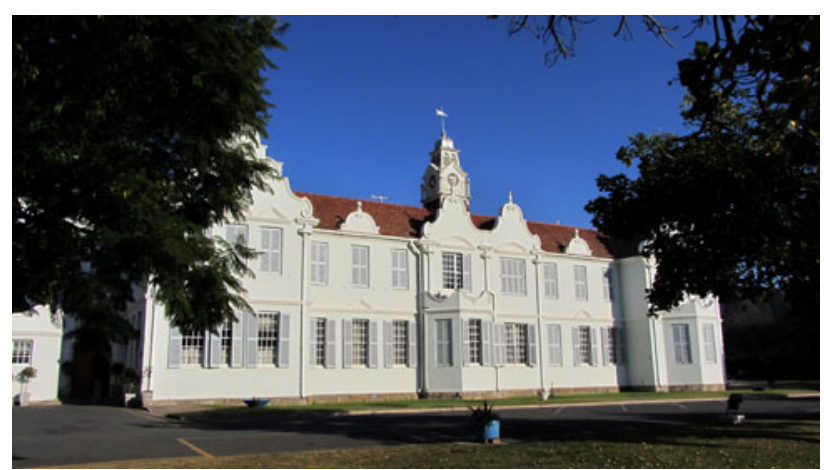

Figure I. Building on College Avenue. Photo: Graaff-Reinet Museum.

time, the Graaff-Reinet College was one of only eight institutions in the Colony to offer this level of education. Originally, the content level was not much higher than matric. This was to be expected in the light of the problems at the level of preparatory and even elementary education. Yet by 1864 the Graaff-Reinet College had become an excellent academic institution, at least at the matriculation level, and by the late 1860s it excelled even at the higher levels. From 1864 to 1869 , a total of 54 candidates from Graaff-Reinet College wrote the examination for the thirdclass certificate; this was the second highest number in the Colony [3]. In 1865 the first prize in Literature and Mathematics [6], and in 1867 the Stockenström Prize as the best student of the year in the Colony, were won by students from Graaff-Reinet. In the following year, the latter student obtained a second-class certificate, a qualification that would later be converted to a Cape B.A. by a university act in 1896. In addition, two students passed the second-class certificate test in Literature and Science in 1867, and in 1868 one of these obtained a first-class certificate in Mathematics, which in 1896 was converted to a Cape M.A. These students from Graaff-Reinet therefore count among South Africa's first locally educated graduates.

Unfortunately, this period of prosperity would not continue. By 1869 the number of students was declining, giving rise to retrenchments and even cuts in the annual salaries of the professors. Thinking at the time that the College would not survive these financial difficulties, Guthrie decided to resign. However, after James Gill left Graaff-Reinet, the decision was made to continue operating the College with only one professor and an assistant. This professorship was offered to Guthrie, and he accepted.

The governing body now looked to Guthrie for advice on how to prepare for the future of the college. In due course he proposed a plan to solve the current problems. The Council accepted most of it with gratitude. Shortly thereafter, Frederick Howe Ely of Cape Town was selected from among 11 applicants to be the new assistant professor, and things started to look up. There were now 33 students, and new classrooms were being built. Guthrie, who believed "the best guarantee for a well-educated family is a well-educated mother", was also one of the first professors in the Colony to promote higher education for women.



Figure 2. Laer Volkskool. Photo: Graaff-Reinet Museum.

Both Guthrie and Ely believed that the preparatory school needed to reopen. By 1873, a permanent preparatory schoolteacher was in place again. Meanwhile, the upper division continued to flourish. In 1873, the Board of Public Examiners in Literature and Science converted to a full examining university (the University of the Cape of Good Hope, which later became University of South Africa). From 1874 onward the terms "second-class certificate" and "firstclass certificate" would be replaced by "Cape B.A." and "Cape M.A.", respectively. For the following 2 years the Graaff-Reinet College continued to function actively as a university college.

In 1874 Guthrie successfully opposed a proposition by the superintendent-general of education that all colleges should restrict themselves to degree work exclusively; he emphasized that the success of the Graaff-Reinet College as a university college was made possible by the fact that it was partly a school as well [3]. Nonetheless, the autonomy of the College was threatened. Unable to accept that it would probably become a state institution, Guthrie finally resigned in 1875 [6], presenting the Council with a new plan for the continued well-being of the College [3]. In recognition of his contributions, the Graaff-Reinet community held a banquet in his honour.

By an Act of Parliament, the College, although still known as the Graaff-Reinet College, became a government highschool on April 30, 1884. For 38 years it flourished in that capacity, and in 1906 it moved into new premises on College Avenue [6]. Since its closing in 1922, these premises have housed different institutions, including the Graaff-Reinet Training College and, currently, the South African Police Academy: Graaff-Reinet (Figure 1).

In 1922, what was left of the Graaff-Reinet College merged with another school to form Hoër Volkskool, the first highschool in the Cape Province with Afrikaans as its only medium of teaching. Figure 2 shows its original location. These buildings currently house Laer Volkskool.

\section{The South African College}

On October 1, 1829, the South African College, or Zuid Afrikaansche Athenaeum, was inaugurated as a private higher-class school with a small upper section preparing 


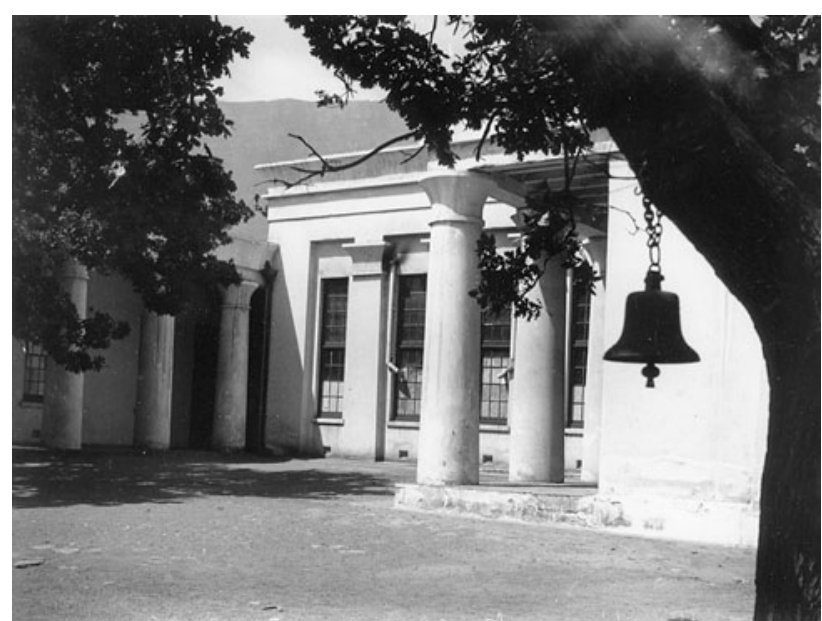

Figure 3. The Egyptian Building. Photo: NASA [7](a).

students for university entrance, with emphasis on science and literature. Funds were raised by public subscription (shareholders), and fees were paid by parents. In 1918, by act of Parliament, the college formally became the University of Cape Town [8].

Guthrie was Professor of Mathematics at the South African College from November 1, 1878, until he retired on January 31, 1899 because of ill health [7](c). The College had first been housed in the Orphan House on Long Street, but before Guthrie's time it moved to what is presently known as the Hiddingh Campus of the University of Cape Town off Orange Street in the Gardens district of Cape Town. The first College building, the so-called Egyptian Building, was erected between 1839 and 1841; it remains unaltered today (Figure 3).

When Guthrie joined the faculty, the College was hardly more than a higher-class school with a small upper section preparing students for the degree examinations of the University of the Cape of Good Hope. The Departments of Classics and Mathematics were both overloaded with hours and work. Guthrie's teaching load became even heavier with the introduction of a separate intermediate class in mathematics in 1883, but the Council could not afford an assistant for him (Figure 4).

Figure 5 shows the Old Slave Lodge ${ }^{1}$ on the South African College campus. This building housed the Departments of Mathematics and History after 1872 . Today it is known as the Quad Building.

Francis Guthrie played an active part in the affairs of the College and was the secretary of the Senate (there being no registrar then) in 1887, 1891, and 1894 [8]. He did not lecture, but gave personal tuition to his students, going to much trouble to help them [4]. He also did some examining work for the University of the Cape of Good Hope. In June 1891, Guthrie wrote to Bolus in Madeira: "I am just on the eve of a long month's incessant work, in the form of some 1600 examination papers, for the School elementary. The prospect is not very cheering, but I must get through it." [2]. An assistant in Mathematics was appointed for him in 1895, but he was also an assistant in French.



Figure 4. Professor Francis Guthrie. Courtesy of Allen John Guthrie.

The first female students entered the College in 1886. In 1895, the Governor's Prize, for general proficiency in all departments, was awarded to one of Guthrie's students, Nellie Brown Muir, eldest daughter of Dr Thomas Muir, the third superintendent-general of education of the Cape Colony. In 1897, she became the first woman to win the Gold Medal for Science. Thomas Muir was one of the greatest organisers and reformers in the history of Cape education. Most of his more than 320 papers were on determinants and allied subjects, and his magnum opus was a five-volume work entitled The Theory of Determinants in the Historical Order of Development (London, 1890-1930) [8].

\section{Guthrie's Projects}

Guthrie was passionately involved in several different projects. In Graaff-Reinet these included serving on the fundraising committee, which led to the founding of the Midland Hospital in 1877, and helping to administer the finances of St James's Church [6]. He also collected the earliest rainfall statistics in Graaff-Reinet [4].

Figure 6 shows the present Old Library Museum on Church Street. This building, which is an extension of the old building, served the town as its library from 1847 until 1981. As a director of the library from 1861 to 1875, Guthrie organised series of lectures as a source of income for the library and developed the library into a cultural centre. These series included seven lectures on astronomy by Rev. George Brown, ten lectures on botany by Guthrie himself, and a

${ }^{1}$ The Slave Lodge in Figure 5 should not be confused with the better known Old Slave Lodge in Adderley Street, Cape Town. 


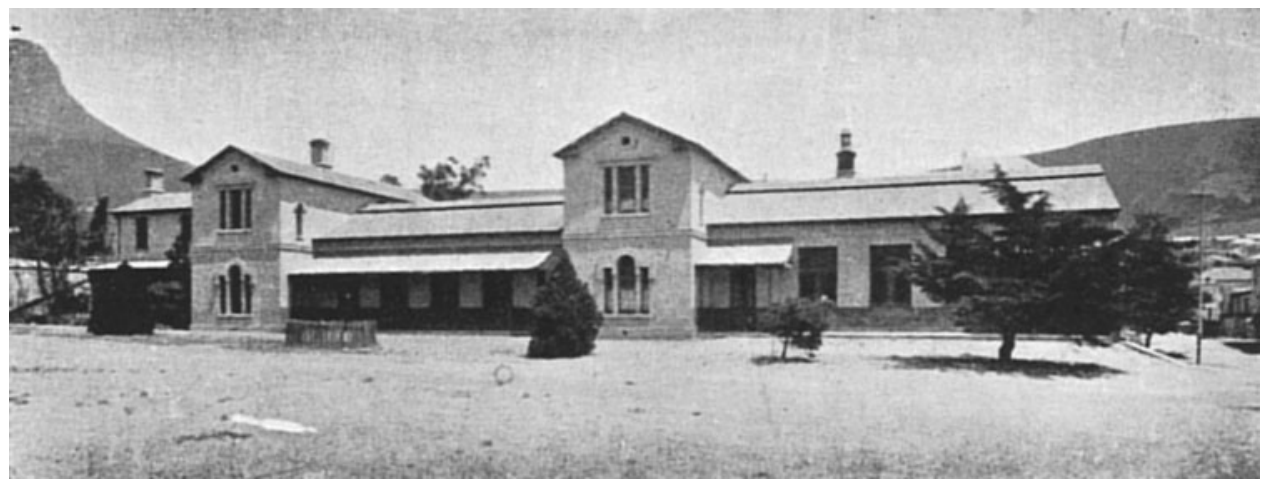

Figure 5. Old Slave Lodge, South African College. Photo: NASA [7](b).

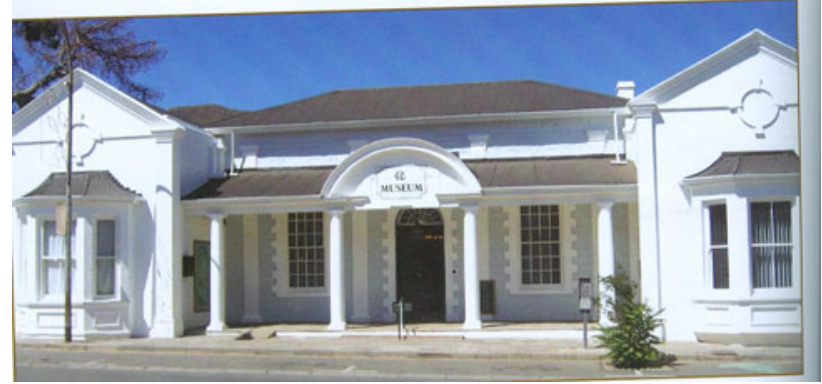

Figure 6. The Old Library Museum. Photo: Graaff-Reinet Museum.

lecture on chemistry by Guthrie's brother, Frederick, who visited Graaff-Reinet from Mauritius.

Figure 7 shows the library, sketched by L. Röhlin, c1855. The building to the left of the library is St James's Church on Somerset Street. This is the oldest church building in GraaffReinet still in use as a church [6].

Guthrie was also responsible for the planning of a route over the unchartered terrain of the Sneeuberge (Snow Mountain) for the railway that would be built through GraaffReinet [1]. There were important reasons for the introduction of such a railway line: the dangerous state of the existing roads, the transport of bales of wool, and later also as a communication link with Kimberley after the discovery of diamonds. Guthrie and Bolus were enthusiastic supporters of railway development in the Midlands [6]. When the agitation for a railway from Port Elizabeth to Graaff-Reinet was at its height (1871-1873), Guthrie fervently supported the midland

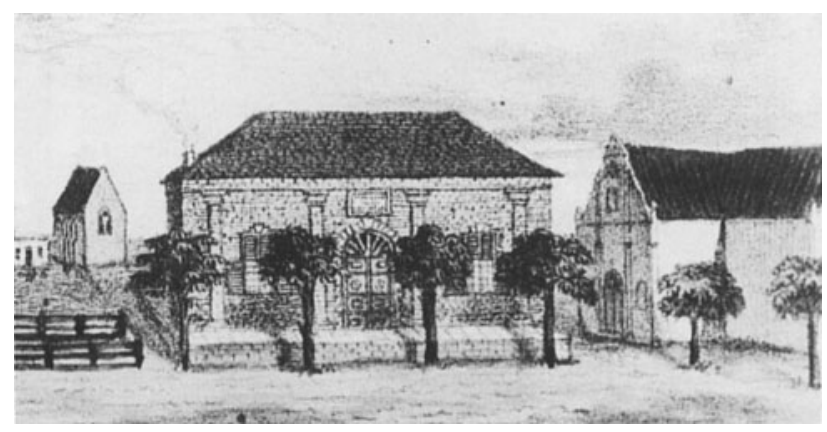

Figure 7. Sketch of library and St James's Church [6]. route, convincing a party of friends to climb the neighbouring mountains and to find the best pass over the Sneeuberge. Their route was adopted and the line was later extended to Middelburg.

Another ambitious project Guthrie undertook was to design a flying machine. Like other people of the time, he thought one needed to study birds, and he studied the wings and proportions of different birds brought to him by his students [1].

Finally, he was intensively involved in irrigation planning in Graaff-Reinet. A dam had been contemplated as early as 1844, and interest in matters of irrigation was again sparked in 1862 when Colonial Engineer Woodford Pilkington presented a lecture on the possibilities of a waterworks scheme. Because of the financial depression in the Colony, these ideals were not realised until the drought in 1865 led to the discovery that strong undercurrents of water, more than 900 litres of pure, clean water per minute, could be obtained by digging in the bed of the Sundays River: the gravel and stones of the river formed a natural filter. The problem was to devise an economical method by which these water currents could be raised. By 1875, the Graaff-Reinet Municipality started to devote serious attention to the development of a waterworks scheme, offering a prize of fifty pounds for the best plan for two dams in the Sundays River. Guthrie's plan, submitted with architect Sidney Stent, received much attention (Figure 8).

Guthrie explained in their proposal that the water was to be drawn off underground and would naturally flow into town through subterranean furrows, which would not be endangered by floods. Tap water to houses would be provided via a reservoir on Magazine Hill, to which river water was to be pumped. Irrigation water was to be diverted into a furrow that would take it directly to town. But the citizens were not prepared to spend money on this kind of venture, and Guthrie's plan was rejected, though the use of unpurified furrow water for domestic purposes was the main cause of the high infant mortality rate in the 1860s. The waterworks scheme eventually introduced by Colonial Hydraulic Engineer John G. Gamble in 1880 was, in fact, to a large extent based on the scheme of Guthrie and Stent [6] (Figures 9, 10).

Guthrie was also a founder and executive member of the South African Philosophical Society (later the Royal Society of South Africa), a member of the Cape Meteorological Commission, and for many years an examiner for the University of the Cape of Good Hope [4]. 


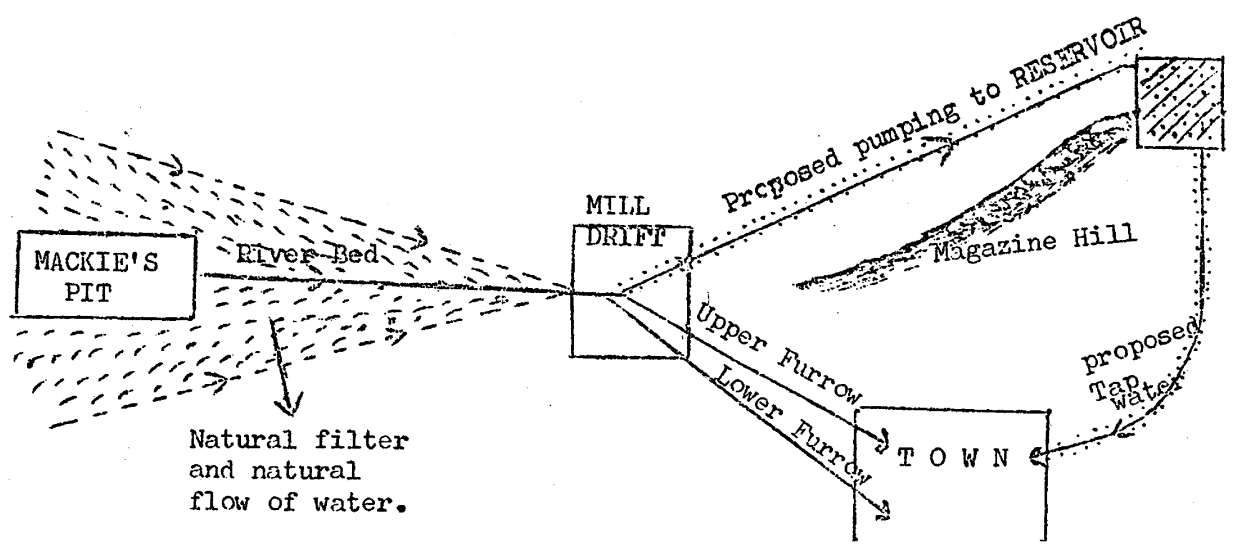

Figure 8. The irrigation scheme of Guthrie and Stent [6].



Figure 9. Laying of the water pipeline from Mackie's Pit, 1883. Photo: Graaff-Reinet Museum.



Figure I 0. Construction of the Mackie's Pit culvert, 1884. Photo: Graaff-Reinet Museum.

\section{Amateur Botanist}

In London, Guthrie had attended the lectures of the botanist John Lindley, and in Graaff-Reinet he lectured on botany often. These lectures inspired Harry Bolus, who would later become a celebrated botanist [2]. Bolus paid tribute to Francis Guthrie as the man who had taught and advised him in his botanical research, and he named a monotypic plant genus after him. This is the genus Guthriea Bolus, presently on the

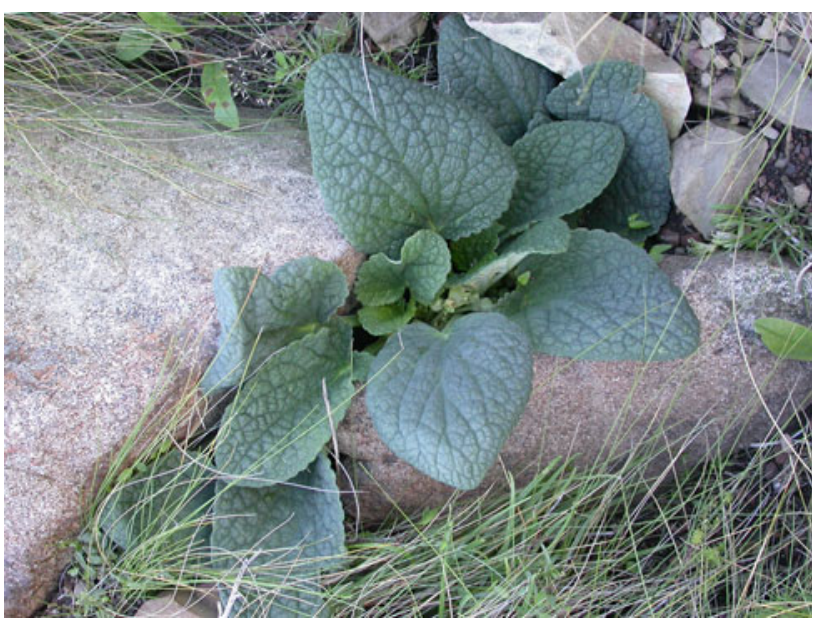

Figure II. Guthriea capensis Bolus, 1873. Photograph by Peter Weston, March 2006. (Courtesy of Vincent Ralph Clark, Rhodes University, Grahamstown.)

Red List of South African Plants. In 1873 Bolus discovered this plant in the grassland on Nardousberg, which at the time was known as Gnadouw-Sneeuwbergen, $40 \mathrm{~km}$ east of GraaffReinet [2] (Figure 11).

About the time of his trip to Kew in 1876, Bolus began to take a special interest in the Orchidaceae; he named Orchidaceae - Satyrium guthriei Bolus (1893) after Guthrie [2]. Together they elaborated the intricate genus Erica. They met at each other's houses on Sunday afternoons to discuss scientific and literary subjects, and from private correspondence between them while Bolus was in England, we obtain some idea of their wide reading [7](e). Their work on the Ericas appears on pages 1-315 in Volume IV of W. H. Harvey, O. W. Sonder, and W. T. Thiselton-Dyer's Flora capensis [2, 9]. Before his death, Guthrie had accumulated an extensive collection of the Cape Peninsula flora. His widow presented his herbarium to the South African College Botany Department, which at that time had no home of its own, but later was transferred to the Botany Department of the University of Cape Town. There are 14 plant species named after Guthrie; Figure 12 shows one of them.

When Guthrie died in 1899, Harry Bolus recorded in his diary, "Francis Guthrie my dear Friend, counsellor, teacher, 


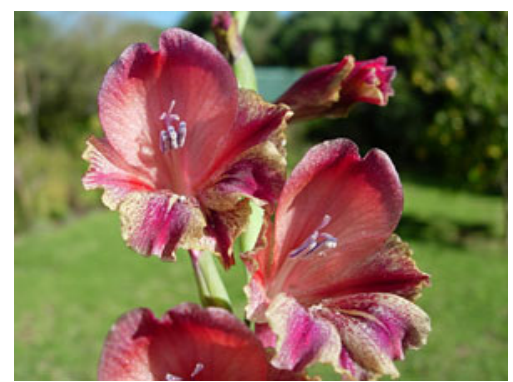

Figure 12. Gladiolus guthriei F Bolus (1917). Photo: Cameron McMaster.

companion and close intimate friend (without break since 1861) died at 11 p.m. at his house." [2]. Guthrie was buried in the graveyard of the St Thomas's Anglican Church at the corner of Camp Ground and Sandown Roads, Rondebosch [4]. This graveyard was converted to secular use in 1976, and the inscriptions from the monuments in the graveyard were recorded in the Memorial Book that can be seen in the Church. Guthrie's inscription in this book reads: "In loving memory of Francis Guthrie, B.A. LL.B, born 22.1.1831 died 19.10.1899." The remains were reburied in the Garden of Remembrance next to the Church in late 1976 (Figures 13, 14).

William Ritchie, Professor of Classics and Guthrie's colleague at the South African College, described Guthrie in [8]: "Kindly and warmhearted, full of quiet humour, hard-working and unassuming, Professor Guthrie has left a warm niche in the hearts of his colleagues and his old pupils. He was somewhat of the old school in his teaching, believed little in lecturing and much in personal tuition, and was ready to spend any time and pains on those who wished to learn. In any tangle or difficulty, such as concocting a College timetable out of innumerable conflicting claims, he was the one invariably appealed to, and his unfailing good humour and patience generally succeeded in unravelling hard knots. He had wide interests beyond his immediate work, was a great reader, and made a special hobby of botany in which he did a large amount of valuable work." (Figure 15)

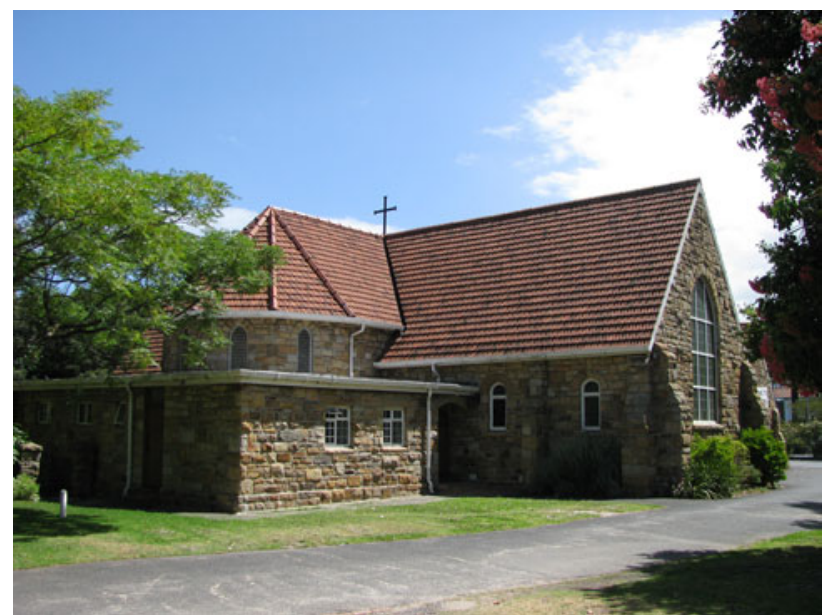

Figure 13. St Thomas's Church. Photo: Pieter Maritz.

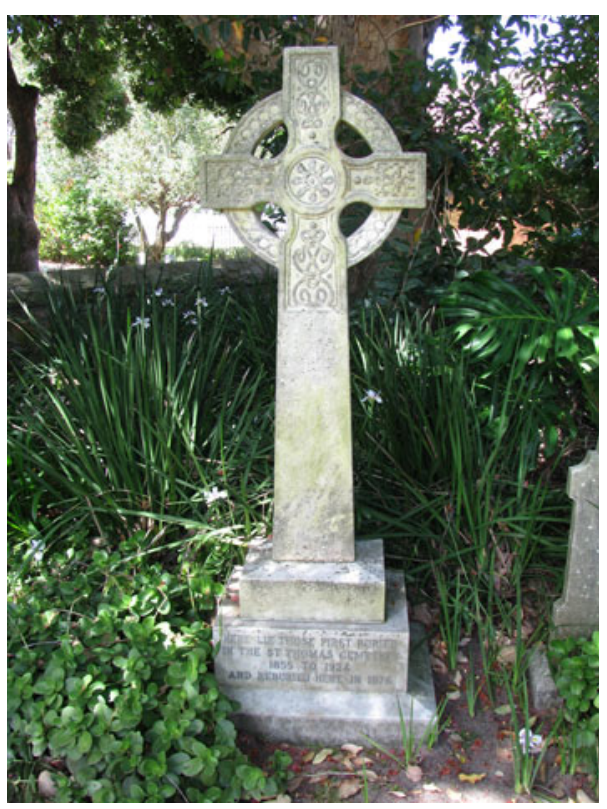

Figure 14. Monument in the Garden of Remembrance. Photograph by Pieter Maritz. The inscription reads: "Here lie those first buried in the St Thomas Cemetery 1855 to 1924 and reburied here in 1976."
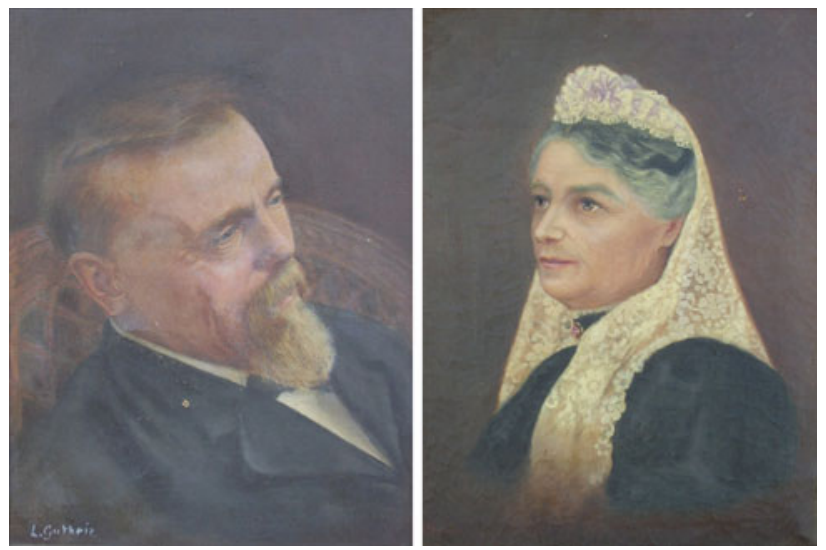

Figure I5. Prof. and Mrs Guthrie, painted by their daughter Louise. Courtesy of Allen John Guthrie.

\section{Guthrie's Publications}

1. The Laws of Magnitude, or The Elementary Rules of Arithmetic and Algebra demonstrated. Trübner \& Co., Paternoster Row, London, pp. 182, 1870.

This mathematics textbook was completely different from the ordinary algebra textbooks of the time. Apparently, the main motivation for the writing of this book was Guthrie's conviction that the elementary laws of magnitude should undergo a thorough metaphysical revision. In addition, he felt that the "reasons" for the rules of arithmetic presented in the usual textbooks were unsatisfactory, because they were rather illustrations than proofs, and often not completely logical. Moreover, since the written examinations (which had been in place since 


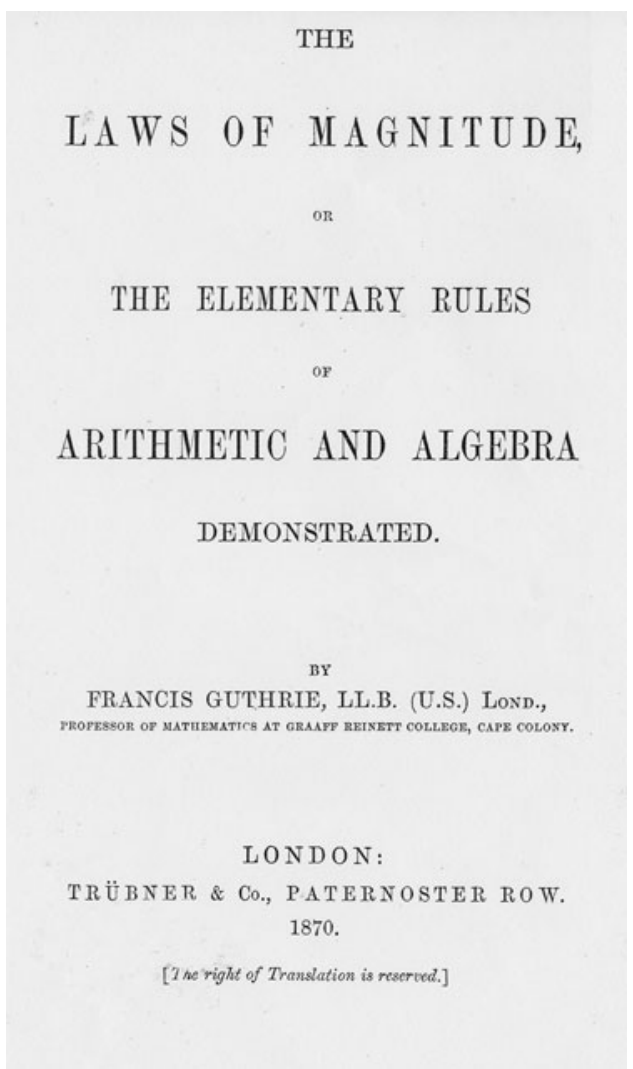

Figure 16. Front page of Guthrie's textbook for schools.

1850) began to contain theoretical questions, the teachers could not continue just to drill their pupils in the mechanical operations of computation, creating a difficulty that this book would try to address.

Some of the features of Guthrie's book were the separation of the various steps of reasoning into distinct propositions and the appearance of both algebraic and verbal statements, which were supposed to remove any danger of ambiguity. It was Guthrie's hope that his book would enable the more advanced students to come to a correct understanding of the theoretical parts of elementary mathematics (Figure 16).

2. On the square root of minus one. The Philosophical Magazine, April 1870.

Although the need for the use of the concept of the square root of -1 was firmly established among mathematicians of the time, they still regarded the symbol $\sqrt{-1}$ with suspicion. Guthrie, in particular, was of the opinion that the justifications given for the use of the symbol at the time were extremely unsatisfactory. In conjunction with his effort to put the laws of abstract magnitude on a simpler elementary footing, in this paper Guthrie extended the definition of the concept of a power, introduced a new symbol, and showed that every result ordinarily deduced by means of the symbol $\sqrt{-1}$ could readily be demonstrated using the new symbol.

3. Continuous Girders, Arched Ribs, and Tension Circles. Transactions of the South African Philosophical Society, Volume I, Part VII, 1877-1878, 127-145(67-85). (Error in page numbering.)
The subject of continuous girders became important with the introduction of railways, where a continuous girder is one that is supported on piers at intervals between the abutments, and is thus divided into two or more spans. The calculation of the strains (distortions of the form of an imperfectly rigid body) and the stresses (forces tending to produce strains) of such a girder is an important process in engineering. The calculation of these strains and stresses had previously been perceived to present certain difficulties in the case of continuous girders. In this paper, Guthrie showed that this was not the case, and that the effect of continuity in altering the strains and stresses of the separate spans could in fact be found using only elementary arithmetic.

4. The Heat of the Sun in South Africa. Transactions of the South African Philosophical Society, Volume I, Part VII, 1877-1878, 45-50.

During the months of September and October in 1868, between 10:00 and 15:00, Guthrie conducted several experiments by which he sought to determine what resources of mechanical power were contained in the radiant heat of the sun in South Africa. Although there were at that time still difficulties in converting the sun's heat into mechanical power, Guthrie was of the opinion that they would certainly be overcome in due course. His results can be summarized as follows: (1) Every square yard (0.84 square meters) of sunshine (meaning the amount of sunshine that falls perpendicularly on a square yard of surface), as long as the sun is not too near the horizon, is equivalent to about one horsepower $(0.75 \mathrm{~kW})$. (This implies that in the sun's heat on a few square kilometres of the surface of the Colony a source of power greater than the whole steam power of Great Britain could be found.) (2) The sun's heat can be collected without reflection or refraction at a temperature that will allow a very large percentage of it to be converted into work.

5. On the free rotation of a rigid body. Transactions of the South African Philosophical Society, Volume II, Part II, 1879-1880, 79-85.

Guthrie mentioned four principal cases of free rigid rotation: (i) when the three principal axes are equal; (ii) when two are equal and less than the third; (iii) when two are equal and greater than the third; and (iv) when all are unequal. In the first three, the problem was completely solved. The fourth led to the solution of elliptic integrals and can only be considered as solved insofar as these integrals are tabulated.

6. On the subjective causes of evolution as illustrated by the geographical distribution of plants. Transactions of the South African Philosophical Society, Volume V, Part II, 1886-1889, 275-294.

The only subjective element of evolution that Darwin expressly recognised was that of hereditary influence, but, according to Guthrie, Darwin did not seem to deny the possibility of the existence of other subjective tendencies. Guthrie's object in this paper was to enquire how far the geographical distribution of plants and other organisms on the earth's surface throws light on this question. Guthrie concluded his paper by mentioning 
that the hypotheses of the supernatural creation of organic life, or of its perpetual existence on Earth, threw no light on its subsequent evolution, whereas the hypotheses of the introduction of organic life by migration or spontaneous generation seemed to lead inevitably to the conclusion that life had originated on Earth. The conclusion was also that life had not, as Darwin supposed, originated from one or a dozen ancestors, but that the process of life introduction was one that was continually going on, or at any rate had to have happened a countless number of times. Whether or not the forms of life thus introduced were countless was another question.

7. Sea levels in South Africa from barometric observations. Transactions of the South African Philosophical Society, Volume V, Part II, 1886-1889, 318-325.

Guthrie showed that barometric observations, continued over a sufficient space of time, were capable of furnishing very useful results related to sea level. This article contains a table showing the heights at 28 different places scattered over the Cape Colony, calculated from the average barometric pressure during the eleven years from 1881 to 1891.

8. Cape Meteorology. South African College Union Annual, No. 3, December 16, 1890, 15-22.

This article contains the substance of a lecture delivered to the Young Men's Christian Association on June 16, 1890. It discusses average rainfall, local distribution of rain, prediction of seasons, the rainfall of South Africa, irrigation, and the effect of vegetation on rainfall.

9. On rain-making. South African College Union Annual, No. 4, December 17, 1891, 21-26.

This article concerns the possible artificial ways to cause rain to fall, such as the dynamite explosions used by the Texans in those days. Guthrie concluded by stating that the research up to that time had shown that when rain was falling or on the point of falling, a concussion might hasten its fall and might even slightly increase the amount of rain.

10. With H. Bolus: Ericaceae. In: Flora capensis. Volume IV, 1-315, edited by W.T. Thiselton-Dyer [9].

\section{ACKNOWLEDGMENTS}

Mark Guthrie, Hermanus, South Africa; Allen John Guthrie, University of Pretoria, South Africa; Anziske Kayster, Graaff-Reinet Museum, South Africa; Cameron McMaster, Napier, South Africa; Ted Oliver, Department of Botany,
University of Stellenbosch, South Africa; Mimi Seyffert, J.S. Gericke Library, University of Stellenbosch, South Africa.

\section{OPEN ACCESS}

This article is distributed under the terms of the Creative Commons Attribution License which permits any use, distribution, and reproduction in any medium, provided the original author(s) and the source are credited.

\section{REFERENCES}

[1] Author unidentified, information supplied by A. Rubidge and R. Rubidge: Professor Guthrie. Graaff-Reinet College Magazine, vol. 1, no. 3 (April 1913), 5-7.

[2] H.A. Baker and E.G.H. Oliver: Ericas in Southern Africa. Purnell, Cape Town, 1967.

[3] M. Boucher: Graaff-Reinet and Higher Education; the years of promise, 1858-1875. KLEIO Bulletin no. 1 vol. VII of the Department of History, University of South Africa (May 1975), 1-21.

[4] Dictionary of South African Biography. Volume II, First Edition. Editor-in-chief: W.J. de Kock (until 1970); D.W. Krüger (since 1971). Published for the Human Sciences Research Council. Tafelberg-Uitgewers Ltd, Cape Town, 1972.

[5] Frederick Guthrie: Note on the Colouring of Maps. Proc. Roy. Soc. Edinburgh 10 (1878-1880), 727-728.

[6] C.G. Henning: Graaff-Reinet. A Cultural History 1786-1886. TV Bulpin, Cape Town, 1975.

[7] National Archives of South Africa, Cape Town Archives Repository: (a) Old Hall and bell, South African College. Jeffreys Collection, Reference J84; (b) Old Slave Lodge, South African College. Jeffreys Collection, Reference J8350; (c) Pension papers and retirement allowance of Professor Guthrie, South African College (Colonial Office ref: 14/3/99). Reference CO 2205, Reference 856, 1899; (d) Death Notice: Francis Guthrie. KAB MOOC, Volume No. 6/9/393, Reference 2760, 1899; (e) E.P. Phillips: $A$ brief historical sketch of the development of Botanical Science in South Africa and the contribution of South Africa to Botany. Pamphlet, p. 49, Reference BP8.

[8] W. Ritchie: The History of the South African College 1829-1918. Volumes I and II. T. Maskew Miller, Cape Town, 1918.

[9] Various authors: Flora Capensis: Being a systematic description of the plants of the Cape Colony, Caffraria \& Port Natal (and neighbouring territories). Volumes IV-VII. Editor: W.T. Thiselton-Dyer. Lovell Reeve \& Co. Ltd, Covent Garden, London, 1904-1909.

[10] R. Wilson: Four Colors Suffice. How the map problem was solved. Princeton University Press, Princeton and Oxford, 2002. 